\title{
DIGITAL SPECTROPHOTOMETER EVALUATION OF THE INFLUENCE OF SCREW COLOR AND ACCESS HOLE FILL ON THE COLOR OF SCREW- RETAINED IMPLANT CROWNS
}

\author{
Sahar Abdel Wahab*
}

\begin{abstract}
Statement of problem: Although screw-retained implant crowns are commonly preferred by clinicians, there remain a limited number of studies on how color affected by screw color and access hole fill.

Purpose: The purpose of this study was to determine the influence of screw color, opaque shade and composite thickness on the color of screw-retained implant crowns with use of digital spectrophotometer.

Materials and Methods: eighty specimens were divided into two groups ,gray group (pure titanium) and golden-colored group (anodized titanium) which used as two backgrounds. Composite discs with $1 \mathrm{~mm}, 2 \mathrm{~mm}, 0.5 \mathrm{~mm}$ opaque $+0.5 \mathrm{~mm}$ composite and $0.5 \mathrm{~mm}$ opaque $+1.5 \mathrm{~mm}$ composite were fabricated. Titanium specimens and composite discs were placed into a collective mold in various tested groups for color measurements.
\end{abstract}

RESULTS: Quantitative in concern to clinical color matching tolerance, It was found that, group $4 \mathrm{~A}$ and $4 \mathrm{~B}$ recorded the lowest $\Delta \mathrm{E}$ as they could not detected by human eyes. Quantative color matching evaluation showed, no significant differences between gray and golden colored titanium(background), $(\mathrm{P}>0.05)$ while golden colored titanium gave higher $\Delta \mathrm{E}$ than grey titanium group. For grey titanium; it was found that Group (4A) was the lowest $\Delta \mathrm{E}$ value $(1.20 \pm 0.4)$, followed by Group (2A) $(4.00 \pm 1.3 \Delta \mathrm{E})$, then Group (3A) $(5.55 \pm 1.8 \Delta \mathrm{E})$ while Group (1A) was the highest $(7.6 \pm 2.53 \Delta \mathrm{E})$ The difference in color change was significantly where $(\mathrm{P}=0.001<0.05)$.

For golden colored titanium; it was found that $\operatorname{Group}(\mathbf{A B})$ recorded the lowest $\Delta E$ value $(1.15 \pm 0.38)$ followed by Group $(2 \mathrm{~B})(3.65 \pm 1.26 \Delta \mathrm{E})$ then Group $(3 B)(4.15 \pm 1.3 \Delta \mathrm{E})$ while Group (1B) was the highest $(5.55 \pm 01.8 \Delta \mathrm{E})$. The difference in color change was significantly where $(\mathrm{P}=0.0001<0.05)$.

Conclusion: composite thickness and opaque shade composite affected $\Delta E$ values $(\mathrm{p}<0.05)$. while, the color of the background did not affect $\Delta \mathrm{E}$ values $(\mathrm{p}>0.05)$ of the color of final restoration.

Clinical implications: Screw color and access hole fill play an important role on the color of screw-retained implant crowns. In present study, regardless the implant color, the use of $0.5 \mathrm{~mm}$ opaque composite covered by $1.5 \mathrm{~mm}$ composite resin affected the color of final restoration significantly.

*Associate Professor of Fixed Prosthodontics Department, Faculty of Dental Medicine For Girls Al-Azhar University 


\section{INTRODUCTION}

Prosthetic reconstruction involving end osseous implants can involve screw-retained or cementretained restorations or both. ${ }^{1}$ The choice of cement versus screw retention seems to be based on mainly the clinician's preference. ${ }^{2}$ Some authors advocate that the screw-retained prosthesis, offers reversibility and more stability and security at the implant-abutment prosthetic interface. ${ }^{3}$ During the life of an implant prosthesis, the clinician may need to remove the restoration for hygiene, repairs, and abutment screw tightening, and screwretained designs make all of these procedures easily achievable. Screw-retained restorations, however, require precise implant placement for optimal location of the screw access hole; deviations from the optimal position and angulation can lead to an unaesthetic restoration. ${ }^{4}$

It has been reported that when comparing screwretained with cemented implant restorations, a measurable difference in health (modified plaque index, bleeding index) was noted, with the cementretained crowns worsening over time. Sinus tracts, inflammation, and continued bone loss have been documented as being related to cement residue remaining in the peri-implant soft tissues. ${ }^{5}$ A recent study reported on the positive relationship between excess cement and peri-implant disease (perimucositis and peri-implantitis). These conditions are classified as inflammatory lesions that may affect the peri-implant tissues, with the potential loss of supporting bone. Although it is possible to treat periimplant disease, prevention is the goal of supportive therapy $^{6}$. Techniques have been developed ${ }^{7,8}$ to minimize the extrusion of luting cement into the peri-implant soft tissues, but it is likely that these issues cannot be predictably eliminated. The inability to completely remove cement from the implant abutment surfaces as well as the difficulties in radiographic detection of some commonly used luting cements have been reported..$^{9,10}$ It would seem better to avoid these problems entirely by using a screw-retained restoration, however, this requires closure of the screw access channel.

The access holes of screw-retained dental implant crowns present an esthetic obstacle for restorative dentists. But little research has focused on comparing the esthetics of the different filling materials. If screw retention is used, the access hole must be filled to help insure the success of the implant restoration; however, many times the esthetics of the restoration are compromised in order to maintain its functionality. ${ }^{11}$ Many commonly used dental restorative materials are relatively translucent and are unable to completely mask the dark, underlying metal oxide layer lining the access hole. These materials include a variety of composites, such as dentin, enamel, and resilient composites. Maintaining the function and retrievability of the implant crowns is important, but attention also needs to be given to providing a crown that is esthetically acceptable to the patient. Therefore, it seems valuable to know if patients and dentists are able to detect a significant difference between these composite filling materials, and if so, it would be worthwhile to determine which materials are viewed as esthetically acceptable by each group. ${ }^{12}$

Instrumental color measurement of translucent materials is influenced by the properties of background. When light is illuminated on a translucent specimen backed by a glossy Iwhite background, many fraction of light reached to the background may be reflected, however, when backed by a mattlblack background or a light trap, the degree of reflection may be reduced significantly. ${ }^{13}$

The color of titanium screw of screw retained implant restoration is commonly gray. Coloring of titanium can be achieved through several techniques with electrolytic oxidation, most commonly used in industry. Anodic oxidation is an electrochemical treatment method that can control the thickness of an oxide layer formed on a titanium surface, and has the advantage in that it can be readily applied 
to materials with complex surface patterns such as implant fixtures. In particular, it can facilitate the adsorption of ions present in the electrolyte to the anodic oxide layer treated with a voltage higher than the breakdown voltage. The electrolyte is an important variable that determines the characteristics of the layer treated by anodic oxidation. In addition, the processing conditions during anodic oxidation play an important role. ${ }^{14}$

A black background color can impact the lightness of the materials and may also cause chromatic changes. In such situations, composite resin restorations can result in grayish shade or poor color match because the translucent materials are affected by the discolored tooth structure or darkness of the oral cavity. To minimize the effect of the background color, opaque shade composite resins have been utilized as a backing by using a layering technique, With this method ,the translucency of the composite resin is as critical as the color of the material itself. ${ }^{15}$ Translucency also affected by the thickness of the composite resins. Accordingly, the translucency and necessary thickness of the underlying opaque shade composite resin must fully understood in order to produce a successful color match for esthetic restoration. ${ }^{16}$

Color measurements using instruments such as colorimeter or spectrophotometer had been established as means of measuring color stability of tooth colored restorative materials. These instruments can detect color differences both objectively and metrically using the CIE LAB system that was established by Commission I'nternationale de LEclairage. ${ }^{17}$

The aim of this study was to determine the influence of screw color and access hole fill on the color of screw-retained implant crowns with use of digital spectrophotometer. Our research hypothesis is that color of the background (gray and golden colored titanium), opaque shade composite and thickness of composite would affect $\Delta \mathrm{E}$ values of final color of restoration.

\section{MATERIALS AND METHODS}

Pure titanium cylinder bars were sectioned with a lath into 80 specimens, $2 \mathrm{~mm}$ in length and $10 \mathrm{~mm}$ in diameter. These specimens divided into two groups, gray group (pure titanium) and goldencolored group (anodized titanium).

Preparation of anodized titanium specimens: these specimens were ground with silica carbon paper from 220 to 600 grit, degreased with acetone, cleaned ultrasonically in absolute ethanol for ten minutes, and dried in a $40^{\circ} \mathrm{C}$ electric oven for 24 hours. The titanium specimens were connected to the anode and gold plate was connected to cathode. The distance between the titanium specimens and gold plate during the anodic oxidation process was $3 \mathrm{~cm}$. An acetic acid used as electrolyte and by a voltage in the $0-100 \mathrm{v}$ range up to reaching the saturation of the process.

Teflon molds fabrication: four custom-designed Teflon molds were fabricated, $14 \mathrm{~mm}$ in diameter and four thickness as follow; $0.5 \mathrm{~mm}, 1 \mathrm{~mm}, 1.5 \mathrm{~mm}$, and $2 \mathrm{~mm}$.

Collective molds fabrication : Two customdesigned nickel chromium molds were fabricated $14 \mathrm{~mm}$ in diameter and two thickness as follow; $3 \mathrm{~mm}$, and $4 \mathrm{~mm}$.

Preparation of composite resin specimens: light cured composites resin (Renamel LC, Cosmedent, Chicago) with shade color A2 and opaque A2 (OA2) were used in this study. Composite specimens were made by condensing composite into a customdesigned Teflon molds with different thickness. In order to achieve a flat and smooth surface the composite resin was pressed between two glass slabs and both surfaces were light polymerized with light source (Astralis, Ivoclar-vivadent, Schaan, Liechtenstein) according to manufacturer's instructions. The specimens stored in distilled water at $37^{\circ} \mathrm{C}$ for 24 hours. In the gray group, the titanium specimen placed inside the collective custom-made 
TABLE (1) Specimens classification and abbreviations.

\begin{tabular}{|c|c|c|c|c|}
\hline \multirow[b]{2}{*}{$\begin{array}{c}\text { Gray } \\
\text { titanium } \\
\text { (Group A) }\end{array}$} & \multicolumn{2}{|c|}{ Composite thickness } & \multicolumn{2}{|c|}{ Opaque shade and composite thickness } \\
\hline & $\begin{array}{l}\text { Subgroup (1A): } \\
\text { Graytitanium+ } \\
\text { 1mmcomposite thick. }\end{array}$ & $\begin{array}{l}\text { Subgroup (2A): } \\
\text { Graytitanium }+ \\
2 \text { mmcomposite thick }\end{array}$ & $\begin{array}{l}\text { Subgroup (3A): } \\
\text { Graytitanium }+0.5 \mathrm{~mm} \\
\text { opaque porcelain }+0.5 \\
\text { composite resin. }\end{array}$ & $\begin{array}{l}\text { Subgroup ( } 4 \mathrm{~A}) \text { : } \\
\text { Gray titanium }+0.5 \mathrm{~mm} \text { opaque } \\
\text { composite }+1.5 \mathrm{~mm} \text { composite } \\
\text { resin. }\end{array}$ \\
\hline $\begin{array}{l}\text { Golden- } \\
\text { colored } \\
\text { titanium } \\
\text { (Group B) }\end{array}$ & $\begin{array}{l}\text { Subgroup (1B): } \\
\text { Golden-colored } \\
\text { titanium+ } \\
\text { 1mmcomposite thick. }\end{array}$ & $\begin{array}{l}\text { Subgroup (2B): } \\
\text { Golden-colored } \\
\text { titanium+ } \\
\text { 2mmcomposite thick }\end{array}$ & $\begin{array}{l}\text { Subgroup (3B): } \\
\text { Golden-colored titanium+ } \\
0.5 \mathrm{~mm} \text { opaque porcelain+ } \\
0.5 \text { composite resin }\end{array}$ & $\begin{array}{l}\text { Subgroup (4B): } \\
\text { Golden-colored titanium+ } \\
0.5 \mathrm{~mm} \text { opaque composite+ } \\
1.5 \mathrm{~mm} \text { composite resin. }\end{array}$ \\
\hline
\end{tabular}

nickel chromium and the composite specimen placed over it in different thickness with different molds. The same procedures in golden-colored titanium (the number of specimens for each group was 10)Table 1.

Preparation of composite resin control groups:

One and two mm composite resins(shade A2) were prepared and color measurements were made against a white background.

Color Measurements : were made with a digital spectrophotometer Vita easy shade (Vita zahnfabrik, Bad sackingen, Germany). Optical contact was achieved by using an optical fluid (refractive index $=1.5$ ) between composite specimens and background. To standardize the external illumination, the head of spectrophotometer was placed on the center of each specimen in a custom fabricated polytertra fluroethylene positioning template to ensure immobilization of the device for accurate measurements. To evaluate the color matching for different specimens and to determine which of them has the most matches to control groups. A screen will be displayed showing how far that the disc specimens were matching the prescribed color of control group in terms of Good, Fair and Adjust (qualitative).
(Good) means that the expert at shade matching may see little or no difference between the specimen and the target shade to which it has been verified. (Fair) means that an expert at shade matching may see noticeable difference the specimen and target shade to which has been verified. (Adjust) means that an expert at shade matching may see a noticeable difference between the specimen and the target shade

Touching the color matching quality assessment box causes a screen to be displayed. These measurements were done with each specimen on different background (gray titanium and golden-colored titanium) to determine CIELAB coordinates of each disc specimen with these backgrounds. This screen shows the positioning of color of disc specimens with respect to color space coordinates value, chroma and hue (L,C,H). The color determinates of specimens were made 6 times consecutively, and the average $\mathrm{L}, \mathrm{C}$ and $\mathrm{H}$ were recorded.

The collected data of different disc specimens were tabulated and illustrated graphically according to verification results of color matching quality and according to the mean values of total color difference $(\Delta \mathrm{E})$ between shade of manufactured disc specimens and control groups. 


\section{Statistical analysis}

Data analysis in color matching evaluation(qualitative) was performed in several steps. Initially, descriptive statistics for each group results. Chi square tests were performed to detect significance effect of each variable (background, opaque composite and composite thickness). Statistical analysis was performed using Assistat software for Windows. $\mathrm{P}$ values $\leq 0.05$ are considered to be statistically significant in all tests.

In color matching evaluation ( $\Delta \mathrm{E}$ values) (quantitative), three way ANOVA tests were performed to detect significance effect of each variable (background, opaque composite and composite thickness). One way ANOVA followed by pair-wise Tukey's post-hoc tests were performed to detect significance between subgroups. Student t-test was performed done to detect significance between stage subgroups.

\section{RESULTS}

A) Color matching evaluation(good, fair and adjust) qualitative

Frequent distribution of color score results for all groups as function of background and opaque shade composite and composite thickness are summarized in table 2 .
Effect of background (gray and golden colored titanium); regardless to opaque shade composite and composite thickness, it was noticed that titanium type groups affected the color non-significantly $(\mathrm{P}=0.8089>0.05)$ where (Gold colored titanium group (good; 6 score, fair; 3 score and adjust; 1 score) while grey titanium group (good; 5 score, fair; 3 score and adjust; 2 score).

Effect of opaque shade composite; irrespective of background it was found that presence of opaque affected the color non-significantly $(\mathrm{P}=$ $0.5354>0.05$ ) where (composite group (good; 4score, fair; 3 score and adjust; 2 score) while Opaque + composite group (good;7 score, fair; 2 score and adjust; 1 score)

Effect of composite thickness; regardless to other variables it was shown that composite thickness affected the color significantly $(\mathrm{P}=0.0451<0.05)$ where (composite 1 $\mathbf{m m}$ was (good;2 score, fair; 4 score and adjust; 4 score $)(\mathrm{P}=0.801>0.05)$, composite $2 \mathrm{~mm}$ was (good;7 score, fair; 3 score and adjust; 0 score $)(\mathrm{P}=1.0>0.05)$,Opaque + composite $0.5 \mathbf{m m}$ was (good; 6score, fair; 2 score and adjust; 1 score) ( $\mathrm{P}=0.766>0.05)$, while Opaque + composite $1.5 \mathbf{m m}$ was (good; 8score, fair; 2 score and adjust; 0 score) $(\mathrm{P}=1.0>0.05)$. The interaction between variables exhibited non-significant p value $(p>0.05)$

TABLE (2) Frequent distribution of color score results for all groups as function of different variables.

\begin{tabular}{|c|c|c|c|c|c|c|c|c|c|c|c|c|}
\hline \multirow{3}{*}{$\begin{array}{l}\text { Variables } \\
\text { Color score }\end{array}$} & \multicolumn{6}{|c|}{ Composite thickness } & \multirow{2}{*}{\multicolumn{3}{|c|}{$\begin{array}{l}\text { Opaque shade } \\
\text { opaque }+0.5 \mathrm{~mm} \\
\text { composite }\end{array}$}} & \multirow{2}{*}{\multicolumn{3}{|c|}{$\begin{array}{l}+ \text { composite } \\
0.5 \mathrm{~mm} \text { opaque+ } \\
1.5 \mathrm{~mm} \text { composite }\end{array}$}} \\
\hline & \multicolumn{3}{|c|}{$1 \mathrm{~mm}$} & \multicolumn{3}{|c|}{$2 m m$} & & & & & & \\
\hline & Good & Fair & Adj & Good & Fair & Adj & Good & Fair & Adj & Good & Fair & Adj \\
\hline Grey titanium & 1 & 4 & 5 & 7 & 3 & 0 & 6 & 2 & 2 & 8 & 2 & 0 \\
\hline $\begin{array}{c}\text { Gold colored } \\
\text { titanium }\end{array}$ & 2 & 4 & 4 & 7 & 3 & 0 & 6 & 3 & 1 & 8 & 2 & 0 \\
\hline
\end{tabular}

Adj. Adjust $\quad($ Tukey's $p<0.05) \quad$ *; significant $(p<0.05) \quad$ ns; non-significant $(p>0.05)$ 
B) Color matching evaluation ( $\Delta \mathrm{E}$ values) quantitative

Color change $(\Delta \mathrm{E})$ results (Mean $\pm \mathrm{SD}$ ) for all groups as function of different variables are summarized in table (3) and figure (1).

Effect of background (gray and golden colored titanium); regardless to other variables it was noticed that titanium type groups affected the color non-significantly $(\mathrm{P}>0.05)$ where grey titanium gave higher $\Delta \mathrm{E}$ than golden colored titanium group.

Effect of opaque; irrespective of background, it was found that presence of opaque affected the color significantly $(\mathrm{P}<0.05)$ where composite group gave higher $\Delta \mathrm{E}$ than Opaque + composite group.

Effect of composite thickness; regardless to other variables, in golden colored titanium, it was shown that composite thickness affected the color significantly $(\mathrm{P}=<0.0001<0.05)$ where in $1 \mathrm{~mm}$ composite was the highest $\Delta \mathrm{E}$ followed by $0.5 \mathrm{~mm}$ opaque $+0.5 \mathrm{~mm}$ composite then $2 \mathrm{~mm}$ composite while $0.5 \mathrm{~mm}$ Opaque $+\mathbf{1} .5 \mathrm{~mm}$ composite was the lowest $\Delta \mathrm{E}$. Pair-wise Tukey's post-hoc test showed non-significant $(\mathrm{p}>0.05)$ difference between $2 \mathrm{~mm}$ composite and $0.5 \mathrm{~mm}$ opaque +2 mmcomposite .

For grey titanium; it was found that it was found

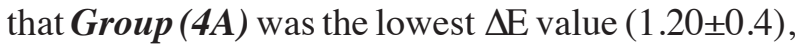
followed by Group (2A) $(4.00 \pm 1.3 \Delta \mathrm{E})$, then Group (3A) $(5.55 \pm 1.8 \quad \Delta \mathrm{E})$ while Group (1A) was the highest $(7.6 \pm 2.53 \Delta \mathrm{E})$. The difference in color change was significantly where $(\mathrm{P}=0.001<0.05)$.

For golden colored titanium; it was found that Group (4B) recorded the lowest $\Delta E$ value $(1.15 \pm 0.38)$ followed by Group $(2 \mathrm{~B})(3.65 \pm 1.26 \Delta \mathrm{E})$ then Group (3B) $(4.15 \pm 1.3 \Delta \mathrm{E})$ while Group (1B) was the highest $(5.55 \pm 01.8 \Delta \mathrm{E})$. The difference in color change was significantly where $(\mathrm{P}=$ $0.0001<0.05)$.

Composite 1mm; it was found that $\operatorname{Group}(1 \mathrm{IA})$ was statistically non-significant higher color change mean value $(7.6 \pm 2.53 \Delta \mathrm{E})$ than Group $(1 \mathrm{~B})$ $(5.55 \pm 1.8 \Delta \mathrm{E})$ where $(\mathrm{P}=0.825>0.05)$.
Composite $2 \mathrm{~mm}$; it was found that $(2 \mathrm{~A})$ was statistically non-significant higher color change mean value $(4.00 \pm 1.3 \Delta \mathrm{E})$ than $(2 \boldsymbol{B})(3.65 \pm 1.26 \Delta \mathrm{E})$ where $(\mathrm{P}=0.183>0.05)$.

Opaque + composite $0.5 \mathrm{~mm}$; it was found that $\operatorname{Group}(3 A)$ was statistically non-significant higher color change mean value $(5.55 \pm 1.8 \Delta \mathrm{E})$ than $\operatorname{Group}((3 \mathrm{~B})(4.15 \pm 1.3 \Delta \mathrm{E})$ where $(\mathrm{P}=0.729>0.05)$.

Opaque + composite $1.5 \mathrm{~mm}$; it was found that Group (4A) was statistically non-significant higher color change mean value $(1.20 \pm 0.4 \Delta \mathrm{E})$ than Group $(4 B)(1.15 \pm 0.38 \Delta \mathrm{E})$ where $(\mathrm{P}=0.563>0.05)$.

TABLE (3) Color change ( $\Delta \mathrm{E})$ results (Mean $\pm \mathrm{SD}$ ) for all groups as function of different variables.

\begin{tabular}{|c|c|c|c|c|}
\hline \multirow{2}{*}{ Variables } & \multicolumn{2}{|c|}{ Composite } & \multicolumn{2}{c|}{ Opaque + composite } \\
\cline { 2 - 5 } & $\mathbf{1 m m}$ & $\mathbf{2 m m}$ & $\mathbf{0 . 5} \mathbf{m m}$ & $\mathbf{1 . 5} \mathbf{m m}$ \\
\hline $\begin{array}{c}\text { Grey } \\
\text { titanium }\end{array}$ & $\begin{array}{c}7.6 \pm \\
2.53(1 \mathrm{~A})\end{array}$ & $\begin{array}{c}4.00 \pm \\
1.3(2 \mathrm{~A})\end{array}$ & $\begin{array}{c}5.55 \pm \\
1.8(3 \mathrm{~A})\end{array}$ & $\begin{array}{c}1.20 \pm \\
0.4(4 \mathrm{~A})\end{array}$ \\
\hline $\begin{array}{c}\text { Golden } \\
\text { colored } \\
\text { titanium }\end{array}$ & $5.55 \pm$ & $3.65 \pm$ & $4.15 \pm$ & $1.15 \pm$ \\
\hline & $1.8(1 \mathrm{~B})$ & $1.26(2 \mathrm{~B})$ & $1.3(3 \mathrm{~B})$ & $0.38(4 \mathrm{~B})$ \\
(P value $)$ & $0.825 \mathrm{~ns}$ & $0.183 \mathrm{~ns}$ & $0.729 \mathrm{~ns}$ & $0.563 \mathrm{~ns}$ \\
\hline
\end{tabular}

*; significant $(p<0.05) \quad n s ;$ non-significant $(p>0.05)$



Fig. (1) Bar chart representing mean values of color change $(\Delta \mathrm{E})$ of different interactions 


\section{DISCUSSION}

In this research, our hypothesis was partially accepted. Composite thickness and opaque shade composite usage affected $\Delta \mathrm{E}$ values $(\mathrm{p}<0.05)$. while, the color of the background did not affect $\Delta \mathrm{E}$ values ( $p>0.05)$ of the color of final restoration.

The aim of this study was to determine the influence of screw color and access hole fill on the color of screw-retained implant crowns with use of digital spectrophotometer.

In previous studies, it was found that the actual thickness of the restorations and corresponding specimen for color measurements are usually 1-2 $\mathrm{mm}$, the color of the background on the color of esthetic restoration would be significant ${ }^{18}$. Unless material thickness is adequate, about 1-1.5 mm , the opacity may be insufficient thereby marring the final color of the restoration ${ }^{19}$. One of the indications in screw-retained implant restorations is limited interocclusal distance that's the reason for selecting $2 \mathrm{~mm}$ of filling material in this study.

In previous studies, it was mentioned that, the composition of alloy significantly affected the color. Gold and cobalt alloys were found to be brighter than nickel chrome and palladium. So, the alloy with high gold content used a reference point for color reproduction..$^{18,19}$. For this purpose, in the present study stand red gray titanium backgrounds were compared with golden-colored backgrounds.

The qualitative color matching evaluation, the mean and standard deviation of the resulting $\Delta \mathrm{E}$ values for each group and compared to the clinical color matching tolerance. ${ }^{20-22}$ (Good means $\Delta \mathrm{E}$ ranged from 0.2-2.7, Fair from 2.4-4.9 and Adjust from 5.5-10.8 according to clinical color matching tolerance). It was found that group $4 \mathrm{~A}$ and $4 \mathrm{~B}$ recorded the lowest $\Delta \mathrm{E}$ as could not detected by human eyes.

In this quantative study, there was no significant differences between $1 \mathrm{~B}, 1 \mathrm{~A}$ or $2 \mathrm{~B}, 2 \mathrm{~A}$ or $3 \mathrm{~B}, 3 \mathrm{~A}$ or $4 \mathrm{~B}, 4 \mathrm{~A}$. So, the color of background (gray and golden -colored titanium) did not affect the color of final restoration. The same finding were confirmed by other studies ${ }^{23}$. However, other results showed that, the light trap can eliminate the influence of background variation on the color measurements ${ }^{26}$. On the contrary, it was found that, Instrumental color measurements of translucent materials influenced by the properties of background. When light is illuminated on translucent specimen backed by a glossylwhite back ground many fraction of light reached to background may be reflected ; however, when backed by mattlblack background or a light trap, the degree of reflection may be reduced significant. ${ }^{27}$

The translucency of opaque shade resin composites was less than the corresponding non-opaque resin composites. As for the color differences between the opaque -shade and the non-opaque shade resin composites were in the perceptible range. In a (through and through) the optical results of the restoration could be affected by both the translucency and the inherent color of the materials. Hence, we must take the color differences of opaque -shade composites into consideration ,as well as translucency of materials, for a clinically acceptable color match of the restoration ${ }^{30-32}$

In our study, the use of $0.5 \mathrm{~mm}$ thick opaque shade and $1.5 \mathrm{~mm}$ composite affected the final color $(\mathrm{p}<0.05)$. Lowest $\Delta \mathrm{E}$ values were obtained in the 4B and 4A groups. This can attributed to opaque shade composite usage. This result is consistent with previous finding which reported that, to minimize the effect of the background color, some opaque-shade resin composites have been utilized as a backing in a so-called layering technique. In the layering technique, more translucent materials over an opaque-shade resin composite are often used to create depth from within the restoration, and help to reduce color coming only from a surface of the restoration. Regarding the translucency of the 
opaque resin composites, some researchers have reported less translucency of the materials ${ }^{31}$.

However, as for the characteristics of the color itself in the opaque resin composites, little information is available ${ }^{29,30}$. In the layering of different resin composite materials, it has been reported that the layered color is influenced not only by the optical properties of the covering layer but also by the color and other optical properties of the underlying layer. ${ }^{34}$ Therefore, it is crucial to know the color and translucency of underlying opaque-shade resin composites in order to establish a successful color match of the layered restoration.

Resilient composite coupled with opaquer (FO), compared to resilient composite(F) alone, yielded improved values. Visual analog scale esthetic values increased from 13.8 and 24.6 in resilient composite to 63.5 and 65.6 in resilient with opaquer between laypersons and dentists, respectively. Acceptability improved from $12 \%$ and $36 \%$ in resilient composite to $76 \%$ and $88 \%$ (FO) between laypersons and dentists, respectively. Both laypersons and dentists are able to detect significant esthetic differences in the materials used to fill the access holes of screwretained dental implants. The data showed that using a small amount of opaquer in combination with filling materials makes a significant esthetic improvement in the implant restoration ${ }^{35-38}$. On the contrary, it was reported that the usage of opaquer under the composites diminished the translucency of composites. ${ }^{39}$

The $2 \mathrm{~A}$ and $2 \mathrm{~B}$ groups showed higher $\Delta \mathrm{E}$ which is higher than the clinically accepted limit 3.3. Although, these test groups gave a lower values than $1 \mathrm{~A}$ and $1 \mathrm{~B}$. Increasing the thickness of composite thickness producing more esthetically restoration. Type, size of filler particles and the pigments affected the color of composite according to their refractive and reflective properties. Thin composite fewer filler particles therefore, more background light is reflected so increasing $\Delta \mathrm{E}^{31,40}$ This explain the results of our study .
There was no significant differences between $3 \mathrm{~A}$, $3 \mathrm{~B}$ groups and $1 \mathrm{~A}, 1 \mathrm{~B}$ groups but $3 \mathrm{~A}$ and $3 \mathrm{~B}$ gave lower $\Delta \mathrm{E}$ due to the usage of opaque composite. The clinical implication of this study is that the usage of $0.5 \mathrm{~mm}$ opaque composite under $1.5 \mathrm{~mm}$ composite resin to fill the access hole in screw-retained implant crowns improve the color regardless the screw color. This is in vitro study presented the limitation such as the usage of cotton pellet over the screw due to difficult in standardization. Also, usage of one type of composite resin.

\section{CONCLUSIONS}

Within the limitation of the present study ,the following conclusions were drawn:

1- The color of background (gray titanium and gold- colored titanium) did not affect the color of final restoration.

2- The usage of $0.5 \mathrm{~mm}$ opaque composite under $1.5 \mathrm{~mm}$ composite resin to fill access hole in screw-retained restorations improved esthetics by masking the color of background.

\section{REFFERENCES}

1. Taylor TD, Agar JR, Vogiatzi T. Implant prosthodontics: Current perspectives and future directions. Int J Oral Maxillofac Implants 2006;15:66-75

2. Papaspyridakos P, Chen CJ, Chuang SK, Weber HP, Gallucci GO. A systematic review of biologic and technical complications with fixed implant rehabilitations for edentulous patients. Int J Oral Maxillofac Implants 2012;27:102-10

3. Rangert B, Jemt T, Jorneus L. Forces and moments on Brånemark implants. Int J Oral Maxillofac Implants 1989; $34: 241-7$.

4. Vigolo P, Majzoub Z, Cordioli GP. In vitro comparison of master casts accuracy in single tooth implant replacement cases. J Prosthet Dent 2006;83:562-6.

5. Weber HP, et al. Peri-implant soft-tissue health surrounding cement- and screw-retained implant restorations: a multi-center, 3-year prospective study. Clin Oral Implants Res 2006;17:375-9. 
6. Lahori M, Rai R, Nagrath R, Kaur M.An insight into different innovative techniques to retrieve cement-retained implant supported prosthesis.Int J Oral Implantol Clinic 2015; 6(1):9-16.

7. Gapski R, Neugeboren N, Pomeranz AZ, Reissner MW. Endo- sseous implant failure influenced by crown cementation: A clini- cal case report. Int J Oral Maxillofac Implants 2008;23:943-946.

8. Mantena SR, Gottumukkala S, Sajjan S, Raju A, Rao B, Iyer M. Implant Failures-Diagnosis and Management. Int J of Clinical Implant Dentistry 2015;2(1):51-9.

9. Kalavathy N, Anantharaj N, Kapoor A, Venkataramani A. Implant Retained Fixed Prosthesis. International Journal of Clinical Implant Dentistry 2015;1(2):85-94.

10. Wadhwani C, Pineyro A. Technique for controlling the cement for an implant crown. J Prosthet Dent 2009;102:57-8

11. Meffert RM. Esthetics versus function: is one more important than the other? Implant Dent. 2002;11:201.

12. Ganz SD. A new light cured material for obturation of screw access canals in fixed-detachable implant prostheses. Implant Soc. 1991;2:12-13.

13. Lee YK, LimC, Kim W. Difference in colour and colour change of dental resin composites by the background. J Oral Rehabilitation2005;32:227-33.

14. Park S ,Lee MH, Bae TS, Seol KW. Effects of anodic oxidation parameters on modified titanium surface.J Biomedical Materials Research 2007;10:422-

15. Kamishima N, Ikeda T, Sano H. Color and translucency of resin composites for layering techniques. J Dental Materials $2005 ; 24: 428-32$.

16. Kim SJ, Son HH, Cho BC, Lee IB, Um CM. Traslucency and masking ability of various opaque shade composite resins.J Dentistry 2009;37:102-7.

17. Commission I'nternationale de LEclairage(CIE). Recommendation on uniform color, space -color difference and equations psychometric color terms. Paris Publication No. 2 CE Publication No.15(E-1.3.1)1978;p-12

18. Tuncer S, Demirci M, Tiryaki M, Ünlü N ,Uysal O. The Effect of a Modeling Resin and Thermocycling on the Surface Hardness, Roughness, and Color of Different Resin Composites. Journal of Esthetic and Restorative Dentistry2016;25(6):404-19
19. Felippe LA, Baratieri LN. Direct resin composite veneers masking the dark prepared enamel surface .Quintessence Int. 2008;31;557-62.

20. Gasparik C, Grecu A, Culic B, Badea M, Dudea D. Shade-Matching Performance Using a New Light-Correcting Device.2015; Journal of Esthetic and Restorative Dentistry 2015;27(5) 285-92.

21. Aboushelib M, Dozic A, Liem J. Influence of framework color and layering technique on the final color of zirconia veneered restorations. Quintessence international 41(5):e84-9 · May 2010

22. Cavalcanti A, Fonseca F, Zago C, Junior R. Efficacy of Gutta-Percha and Polytetrafluoroethylene Tape to Microbiologically Seal the Screw Access Channel of Different Prosthetic Implant Abutments: Gutta-Percha, PTFE Efficacy to Seal Screw Channel $\cdot$ Apr $2015 \cdot$ Clinical Implant Dentistry and Related Research

23. Kourtis SG, Tripodakis AP, Doukoudakis AA. Spectrophotometric evaluation of optical influence of different metal alloys and porcelain in the metal-ceramic complex .J Prosthet Dent 2005;92;477-85.

24. Abdel-wahab S.Digital spectrophotometer analysis of opaque porcelain fired to different base metal alloys of metal-ceramic restorations .Egypt Dent J ;2012;58;15-30.

25. Kurt M, Ural C, Kulunk T ,Sanal A, Erkocak A.The effect of screw color and technique to fill acess hole on final color of screw -retained implant crowns.J Oral Implantol. 2011;3:673-9.

26. Lee YK, Lim BS, Kim CW. Effect of surface conditions on the color of dental resin composites. J Biomed Mater Res, 2002;63:657-63.

27. Yu B, Lee YK. Influence of color parameters of resin composites on their translucency. J Dental Materials 2008;24;1236-42

28. Murata Y, Sano H. Translucency of opaque -shade resin composites .American J Dentistry2010;17(2);127-30

29. Wadhwani C, Pin eyro A, Avots J. An esthetic solution to the screw-retained implant restoration: Introduction to the implant crown adhesive plug:Clinical report. J Esthet Restor Dent 2011;23:138-43.

30. Najeeb S, Zafar S, Khurshid Z, Siddiqui F. Applications Of polyetheretherketone (PEEK) in oral implantology and prosthodontics. J of Prosthodontic Research 2016; 60:12-19 
31. Jarad FD, Giffith CE, Jaffri M ,Adeyemi AA, Youngson $\mathrm{CC}$. The effect of bleaching, varying the shade or thickness of composite veneers on final color : an in vitro study. J Dent ;2008;36;554-9.

32. Tanimura R, Suzuki S. In vitro evaluation of a modifieded 4-METAIMMA-TBB resin for filling acess holes of screw retained implant prostheses .J Biomedical Mater Restorat 2014;00B,1-7.

33. Weininger B, McGlumphy E,Beck M. Esthetic Evaluation of Materials Used to Fill Access Holes of Screw-Retained Implant Crowns.2008; J Oral ImplantoL;34(3)145-9.

34. Sumino N, Tsubota K, Takamizawa T, Shiratsuchi K, Miyazaki M, et al.Comparison of the wear and flexural characteristics of flowable resin composites for posterior lesions. Acta Odontol Scand 2013;71:820-27.

35. Yatani H. Esthetic prosthodontic treatment - The state- ofthe art. J of Prosthodontic Research, 2015;59: 216-219.
36. Catelan A, Guedes A, Suzuki A, Takahashi M, Souza E, DDS, Briso A, Santos P. Fluorescence Intensity of Composite Layering Combined with Surface Sealant Submitted to Staining Solutions, J of Esthetic and Restorative Dentistry ;2015 27:Issue Supplement S1, S33-S40

37. Perroni A, Amaral C, Kaizer M, Moraes R, Boscato N. Shade of Resin-Based Luting Agents and Final Color of Porcelain Veneers. J of Esthetic and Restorative Dentistry;2016;15:112-6.

38. Hirata R, Kabbach W, Andrade O, Bonfante E, Giannini M, et al. Bulk Fill Composites: An Anatomic Sculpting Technique. Journal of Esthetic and Restorative Dentistry,2015; 27( 6): 335-43.

39. Hirata R, Kabbach W, Scopin de Andrade O, A Bonfante E, Giannini M, et al.Bulk-fill composite, part I,J of Esthetic and restorative Dentistry,2015;5:176-9.

40. Edward J. Comparison of the CIELab and CIEDE2000 color difference formulas. J of Prosthetic Dentistry, 2016;115:65-70. 